\title{
Assessment of Undiscovered Continuous Oil and Gas Resources in the Hanoi Trough, Vietnam, 2017
}

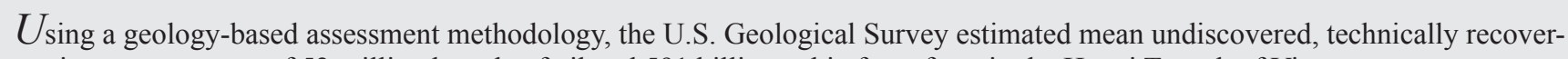
able continuous resources of 52 million barrels of oil and 591 billion cubic feet of gas in the Hanoi Trough of Vietnam.

\section{Introduction}

The U.S. Geological Survey (USGS) quantitatively assessed the potential for undiscovered, technically recoverable continuous oil and gas resources in the Hanoi Trough of Vietnam (fig. 1). The Hanoi Trough represents the onshore part of the Song Hong Basin (Nielsen and others, 1999; Hiep, 2015; Lei and others, 2015). The structural evolution of the Hanoi Trough is linked to the dynamics of the regional Red River fault zone, which can be traced from Tibet eastward more than 1,000 kilometers to the Hanoi Trough and into the Gulf of Tonkin. From the late Eocene through the early Miocene, the Red River fault zone was a transtensional, left-lateral fault that divided into several strands, forming several horsts and grabens that define the Hanoi Trough (Rangin and others, 1995; Hiep, 2015). In the middle Miocene, coincident with cessation of seafloor spreading in the South China Sea, the movement on the Red River fault changed to transpressional with minor inversion and uplift in the Hanoi Trough. Since the end of the Miocene, the Red River fault has been a dextral fault with little or no movement. Within the grabens of the Hanoi Trough, sediments can be as much as 6 kilometers thick. The latest Eocene to early Oligocene synrift sediments are predominantly fluvial to marginal lacustrine conglomerates and sandstones and deep-water, organic-rich lacustrine shales. From the late Oligocene to Miocene, the grabens filled with fluvial, deltaic, and estuarine clastics with intercalated coals and lignites (Nielsen and others, 1999; Wysocka and Świerczewska, 2005). The principal petroleum source rocks in the Hanoi Trough are late Eocene-early Oligocene, organic-rich lacustrine shales and Neogene coals and lignites.

\section{Total Petroleum Systems and Assessment Units}

The USGS defined a Hanoi Trough Oligocene Lacustrine Total Petroleum System (TPS) with the Hanoi Trough Oligocene Lacustrine Shale Oil Assessment Unit (AU) and the Hanoi Trough Oligocene Lacustrine Shale Gas AU, based on mapping by Hiep (2015). Organic-rich lacustrine shales in rift basins in northern Vietnam are up to 500 meters thick, and the organic matter is predominantly Type I with lesser amounts of Type III. Total organic carbon contents are up to 8 weight percent (Nielsen and others, 1999, 2007; Petersen and others, 2001). Lacustrine source rocks in the AU are interpreted to be within the thermal window for oil generation, although a small area is in the thermal gas generation window (Hiep, 2015). The geologic model is for oil and gas to have been generated from these Oligocene lacustrine shales and for some portion of the oil and gas to have been retained within the shales following migration. The Hanoi Trough Neogene Coalbed Gas TPS and the Hanoi Trough Neogene Coalbed Gas AU were defined in this study for potential biogenic gas to have been generated and retained within the shallow, thermally immature coals and lignites.

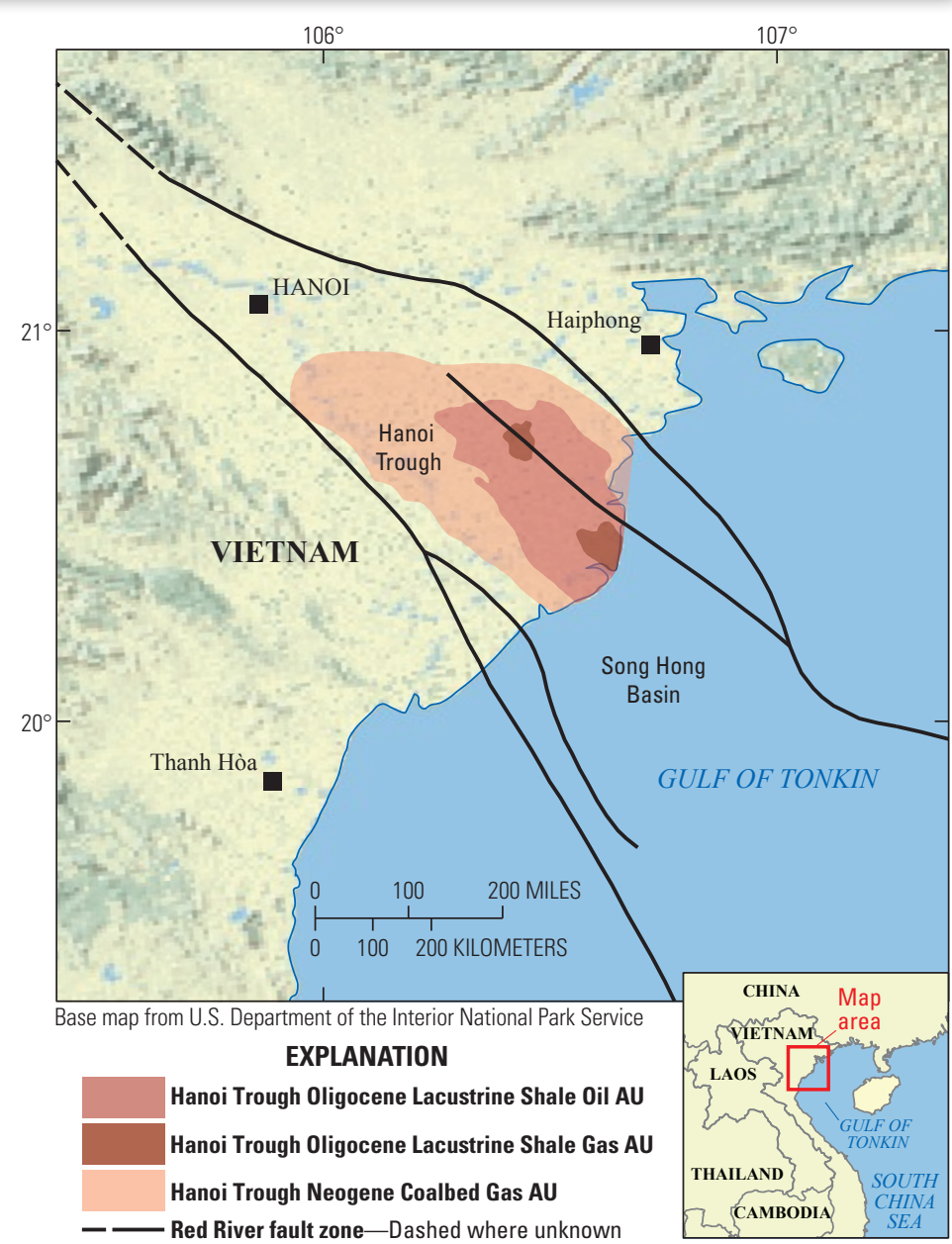

Figure 1. Map showing the location of three continuous assessment units (AUs) in the Hanoi Trough of Vietnam.

The assessment input data are summarized in table 1. Input data for well-drainage areas, success ratios, and estimated ultimate recoveries are derived from analog shale-oil, shale-gas, and coalbedgas assessment units in the United States.

\section{Undiscovered Resources Summary}

The USGS quantitatively assessed undiscovered continuous oil and gas resources in three AUs in the Hanoi Trough of Vietnam (table 2). The estimated mean total for continuous oil resources is 52 million barrels of oil (MMBO) with an F95-F5 range from 0 to $127 \mathrm{MMBO}$. The estimated mean total for continuous gas is 591 billion cubic feet of gas (BCFG) with an F95-F5 range from 147 to 1,210 BCFG. 
Table 1. Key assessment input data for three continuous assessment units in the Hanoi Trough of Vietnam.

[AU, assessment unit; \%, percent; EUR, estimated ultimate recovery per well; MMBO, million barrels of oil; BCFG, billion cubic feet of gas. Well drainage area, EUR, and success ratio are from U.S. shale-gas, shale-oil, and coalbed-gas analogs. The average EUR input is the minimum, median, maximum, and calculated mean. Shading indicates not applicable]

\begin{tabular}{|c|c|c|c|c|c|c|c|c|}
\hline \multirow[b]{2}{*}{ Assessment input data-Continuous AUs } & \multicolumn{4}{|c|}{ Hanoi Trough Oligocene Lacustrine Shale Oil AU } & \multicolumn{4}{|c|}{ Hanoi Trough Oligocene Lacustrine Shale Gas AU } \\
\hline & Minimum & Mode & Maximum & $\begin{array}{c}\text { Calculated } \\
\text { mean }\end{array}$ & Minimum & Mode & Maximum & $\begin{array}{c}\text { Calculated } \\
\text { mean }\end{array}$ \\
\hline Potential production area of AU (acres) & 800 & 155,000 & 310,000 & 155,267 & 800 & 17,174 & 34,348 & 17,441 \\
\hline Average drainage area of wells (acres) & 40 & 120 & 200 & 120 & 80 & 120 & 160 & 120 \\
\hline Success ratio $(\%)$ & 10 & 50 & 90 & 50 & 10 & 50 & 90 & 50 \\
\hline Average EUR (MMBO, oil; BCFG, gas) & 0.04 & 0.08 & 0.2 & 0.086 & 0.1 & 0.25 & 0.7 & 0.273 \\
\hline AU probability & 0.9 & & & & 0.9 & & & \\
\hline \multirow[b]{2}{*}{ Assessment input data-Continuous AU } & \multicolumn{4}{|c|}{ Hanoi Trough Neogene Coalbed Gas AU } & & & & \\
\hline & Minimum & Mode & Maximum & $\begin{array}{c}\text { Calculated } \\
\text { mean }\end{array}$ & & & & \\
\hline Potential production area of AU (acres) & 800 & 426,500 & 853,000 & 426,767 & & & & \\
\hline Average drainage area of wells (acres) & 40 & 80 & 120 & 80 & & & & \\
\hline Success ratio $(\%)$ & 40 & 60 & 80 & 60 & & & & \\
\hline Average EUR (BCFG) & 0.08 & 0.2 & 0.4 & 0.215 & & & & \\
\hline AU probability & 1.0 & & & & & & & \\
\hline
\end{tabular}

Table 2. Assessment results for three continuous assessment units in the Hanoi Trough of Vietnam.

[MMBO, million barrels of oil; BCFG, billion cubic feet of gas; NGL, natural gas liquids; MMBNGL, million barrels of natural gas liquids. Results shown are fully risked estimates. For gas accumulations, all liquids are included in the NGL category. F95 represents a 95-percent chance of at least the amount tabulated; other fractiles are defined similarly. Fractiles are additive under the assumption of perfect positive correlation. Shading indicates not applicable]

\begin{tabular}{|c|c|c|c|c|c|c|c|c|c|c|c|c|c|c|}
\hline \multirow{3}{*}{$\begin{array}{l}\text { Total petroleum systems and } \\
\text { assessment units (AUs) }\end{array}$} & \multirow{3}{*}{$\begin{array}{c}\text { AU } \\
\text { probability }\end{array}$} & \multirow{3}{*}{$\begin{array}{c}\text { Accumulation } \\
\text { type }\end{array}$} & \multicolumn{12}{|c|}{ Total undiscovered resources } \\
\hline & & & \multicolumn{4}{|c|}{ Oil (MMBO) } & \multicolumn{4}{|c|}{ Gas (BCFG) } & \multicolumn{4}{|c|}{ NGL (MMBNGL) } \\
\hline & & & F95 & F50 & F5 & Mean & F95 & $\mathrm{F} 50$ & F5 & Mean & F95 & F50 & F5 & Mean \\
\hline \multicolumn{15}{|c|}{ Hanoi Trough Oligocene Lacustrine Total Petroleum System } \\
\hline Hanoi Trough Oligocene Lacustrine Shale Oil AU & \begin{tabular}{|l|}
0.9 \\
\end{tabular} & Oil & 0 & 46 & 127 & 52 & 0 & 36 & 106 & 42 & 0 & 0 & 1 & 0 \\
\hline Hanoi Trough Oligocene Lacustrine Shale Gas AU & 0.9 & Gas & & & & & 0 & 16 & 43 & 18 & 0 & 0 & 1 & 0 \\
\hline \multicolumn{15}{|c|}{ Hanoi Trough Neogene Coalbed Gas Total Petroleum System } \\
\hline Hanoi Trough Neogene Coalbed Gas AU & 1.0 & Gas & & & & & 147 & 488 & 1,061 & 531 & 0 & 0 & 0 & 0 \\
\hline Total undiscovered continuous resources & & & 0 & 46 & 127 & 52 & 147 & 540 & 1,210 & 591 & 0 & 0 & 2 & 0 \\
\hline
\end{tabular}

\section{References Cited}

Hiep, H.H., 2015, Onshore Vietnam-Basin with shale resource potential: Coordinating Committee for Geoscience Programmes in East and Southeast Asia (CCOP) Workshop on Unconventional Oil and Gas Resources, Daejeon, Korea, June 8-12, 2015, 37 p., accessed June 10, 2017, at http://ccop.asia/uc/data/41/docs/ Vietnam-CountryReport_Vietnam_presentation.pdf.

Lei Chao; Ren Jianye; Sternai, Pietro; Fox, Matthew; Willett, Sean; Xie Xinong; Clift, P.D.; Liao Jihua; and Wang Zhengfeng, 2015, Structure and sediment budget of Yinggehai-Song Hong Basin, South China Sea-Implications for Cenozoic tectonics and river basin reorganization in Southeast Asia: Tectonophysics, v. 655, p. $177-190$.

Nielsen, L.H.; Mathiesen, Anders; Bidstrup, Torben; Vejbæk, O.V.; Dien, P.T; and Tiem, P.V., 1999, Modeling of hydrocarbon generation in the Cenozoic Song Hong Basin, Vietnam-A highly prospective basin: Journal of Asian Earth Sciences, v. 17, nos. 1-2, p. 269-294.
Nielsen, L.H; Petersen, H.I; Thai, N.D; Duc, N.A; Fyhn, M.B.W; Boldreel, L.O; Tuan, H.A; Lindström, Sofie; and Hien, L.V., 2007, A middle-upper Miocene fluvial-lacustrine rift sequence in the Song Ba Rift, Vietnam-An analogue to oil-prone, small-scale continental rift basins: Petroleum Geoscience, v. 13, p. 145-168.

Petersen, H.I; Andersen, C.B; Anh, P.H; Bojesen-Koefoed, J.A; Nielsen, L.H; Nytoft, H.P; Rosenberg, Per; and Thanh, L., 2001, Petroleum potential of Oligocene lacustrine mudstones and coals at Dong Ho, Vietnam-An outcrop analogue to terrestrial source rocks in the greater Song Hong Basin: Journal of Asian Earth Sciences, v. 19, nos. 1-2, p. 135-154.

Rangin, Claude; Klein, M.W.; Roques, Delphine; Le Pichón, Xavier; and Van Trong, Le, 1995, The Red River fault system in the Tonkin Gulf, Vietnam: Tectonophysics, v. 243, nos. 3-4, p. 209-222.

Wysocka, Anna, and Świerczewska, Anna, 2005, Tectonicallycontrolled sedimentation of Cenozoic deposits from selected basins along the Vietnamese segment of the Red River Fault Zone: Acta Geologica Polonica, v. 55, no. 2, p. 131-145.

\section{Hanoi Trough Assessment Team}

Christopher J. Schenk, Marilyn E. Tennyson, Tracey J. Mercier, Cheryl A. Woodall, Phuong A. Le, Timothy R. Klett, Thomas M. Finn, Heidi M. Leathers-Miller, Stephanie B. Gaswirth, and Kristen R. Marra

\section{For More Information}

Assessment results are also available at the USGS Energy Resources Program website at https://energy.usgs.gov. 